\title{
Global energy governance: a review and research agenda
}

Thijs Van de Graaf ${ }^{1}$ and Jeff Colgan ${ }^{2}$

\begin{abstract}
Over the past few years, global energy governance (GEG) has emerged as a major new field of enquiry in international studies. Scholars engaged in this field seek to understand how the energy sector is governed at the global level, by whom and with what consequences. By focusing on governance, they broaden and enrich the geopolitical and hard-nosed security perspectives that have long been, and still are, the dominant perspectives through which energy is analysed. Though still a nascent field, the literature on GEG is thriving and continues to attract the attention of a growing number of researchers. This article reviews the GEG literature as it has developed over the past 10 years. Our aim is to highlight both the progress and limitations of the field, and to identify some opportunities for future research. The article proceeds as follows. First, it traces the origins of the GEG literature (section "Origins and roots of GEG research"). The subsequent sections deal with the two topics that have received the most attention in the GEG literature: Why does energy need global governance (section "The goals and rationale of global energy governance")? And, who governs energy (section "Mapping the global energy architecture")? We then address a third question that has received far less attention: How well or poor is energy governed (section "Evaluating global energy governance")? In our conclusions (section "Conclusions and outlook"), we reflect on the current state of GEG, review recent trends and innovations, and identify some questions that warrant future consideration by scholars. This article is published as part of a thematic collection on global governance.
\end{abstract}

\section{Origins and roots of global energy governance (GEG) research}

- he term "GEG" emerged in about the same period as the G8 picked up the theme at its Gleneagles summit in 2005. Two drivers led both the G8 and academic scholars to turn their attention to energy: growing concern over energy security in the wake of steadily rising oil prices and the first Russia-Ukrainian gas dispute of January 2006, and growing concern over climate change. Not surprisingly, one of the first academics to actually use the term "GEG" was a G8-expert, Kirton (2006), and one of the first topics to be scrutinized by academics was precisely the G8's work on energy (Lesage et al., 2009).

Two research programmes further propelled research in this area. The first was a research project entitled "Changing Rules of the Game: Global Energy Governance in the $21^{\text {st }}$ Century", which ran from January 2008 to December 2009 at the Global Public Policy Institute, an independent think tank based in Berlin. The project's objective was to examine the rules governing three areas of global oil and gas governance: financial markets, trade and investment agreements, and supply (risk) management. ${ }^{1}$ The main output of the project was an edited

\footnotetext{
${ }^{1}$ Department of Political Sciences, Ghent University, Gent, Belgium ${ }^{2}$ Department of Political Science and Watson Institute for International and Public Affairs, Brown University, Providence, RI, USA (e-mail: jeff_colgan@brown.edu) Correspondence: (e-mail: thijs.vandegraaf@ugent.be)
} 
volume entitled "Global Energy Governance: The New Rules of the Game", which was published by the Brookings Institution Press in January 2010 (Goldthau and Witte, 2010).

The second research programme was the Study Group on Global Energy Governance, convened by Ann Florini and Navroz Dubash. This study group was part of the 3-year S.T. Lee Project on Global Governance, organized by the Lee Kuan Yew School of Public Policy at the National University of Singapore (NUS). ${ }^{2}$ The project's goal was to examine the institutions that directly and indirectly govern energy, and the interactions across, and gaps between, those institutions. But the study group also payed particular attention to the implications for energy governance of the rise of Asia in world politics. The group convened twice at NUS, once in October 2009 and again in May in 2010. The work of the study group resulted in the publication of a special issue of Global Policy in September 2011 (Florini and Dubash, 2011).

Early writings approached the subject of GEG from two entry points. One entry point, mostly espoused by energy security specialists, was to criticize the "lopsided attention to the geopolitical dimension of energy security", which is allegedly based on the "myopic and erroneous presumption that global energy politics is necessarily a zero-sum game in which one country's energy security is another's lack thereof" (Goldthau and Witte, 2009: 373). Adopting a lense of global governance brings to the fore a critical set of actors and structures that geopolitics neglects, most notably markets and institutions (the latter referred to as the "rules of the game"). Another entry point, mostly adopted by global governance specialists, asked "why this policy field-closely related to such policy fields as trade, environment, and climate, where multilateral global governance efforts are concentrated-is scarcely governed cooperatively, despite the growing necessity for multilateral governance" (Westphal, 2006: 44; see also Lesage et al., 2010a).

Needless to say, scholars had been studying international energy cooperation well before 2005, just not under the rubric of "GEG". Some of these studies are well known, such as Keohane's (1984) treatment of the oil consumers' regime in his seminal work After Hegemony. Others are less well known, judging by the paucity of citations to these works, but certainly no less interesting. They include Kohl's (1983) work on international institutions for energy management; Cowhey's (1985) work on how nation-states, international organizations and multinational corporations have coordinated their actions to manage the energy market; and Kapstein's (1990) analysis of Western alliance relations during the major energy crises after World War II up until the 1980s.

This list, far from exhaustive, merely serves to drive home the point that energy cooperation has received some attention in the literature but has not given way to an integrated research programme. Research on energy, especially its international dimensions, has largely been "descriptive, atheoretical and noncumulative" (Wilson, 1987). In a recent survey of the literature, Hughes and Lipscy (2013) came to the conclusion that "many of the important questions in the politics of energy remain unanswered or are only beginning to be addressed". It is illustrative, for example, to note how energy has been overlooked within the large research programme on international regimes. Krasner's (1983) seminal volume on International Regimes does not feature a chapter or case study on energy. While some authors have applied the regime concept to the policy field of oil (Keohane, 1984; Maswood, 1990), others have argued that an international regime has never existed in the history of the petroleum industry. Bull-Berg (1985), for example, argues that the postwar international energy system could at best be described as an “imposed order".
There are four basic explanations for the under-theorization of energy (Van de Graaf et al., 2016). First, many of the acknowledged energy experts are not particularly worried about theory. Rather, their concern lies with the short-run prospects for the market and with the question of how governments, corporations and other actors should respond (Strange, 1994). Second, there are high barriers to entry to a field such as energy that requires a dose of technical understanding. Third, the multifaceted nature of energy as a policy area-straddling political science, economics and a host of other social sciences-makes it defy unidisciplinary analysis. Finally, the 1980s and 1990s witnessed a relative cut in social science funding for energy research since the "heyday" of the 1970s (Lutzenhiser and Shove, 1999).

\section{The goals and rationale of GEG}

Today's energy transitions. After two decades of relative neglect, political scientists and international relations scholars have rediscovered energy as a worthy research topic (Hughes and Lipscy, 2013). One reason for the renewed interest is the set of dramatic transitions that are currently underway in the global energy market. Here we discuss three central trends and transformations: climate change, geopolitical change, and increasing volatility in oil and gas markets. ${ }^{3}$ It is these transitions that have prompted scholars to examine energy from a global governance perspective, and as these transitions continue to evolve, their impact on the institutional architecture of GEG will require further investigation.

Arguably the most important transition is linked to the issue of global climate change and the need to decarbonize the global economy. Energy production and consumption is the single largest source of greenhouse gas (GHG) emissions, representing almost $70 \%$ of global emissions (International Energy Agency (IEA), 2014: 7). States and markets have been slow to change, and world carbon emissions continue to rise. Still, to the extent that states take meaningful action to reduce GHG emissions, this is very likely to create incentives for a significant change in fuel choices and energy production patterns. Incentives will shift away from consumption based on heavily emitting sources, such as coal and petroleum, towards low-emitting sources, such as wind, solar, geothermal and hydroelectric power. New governance structures and networks will be necessary to create the incentives for such a shift and to manage the consequences of it. With the emergence of institutions like the International Renewable Energy Agency (IRENA) and the Renewable Energy and Energy Efficiency Partnership (REEEP), the first stages of this institutional development are already under way. In the run-up to the climate conference in Paris in late 2015, for the first time ever, almost all of the world's countries have committed to reducing or controlling their own GHG emissions.

A second major transition comes from geopolitical change. The two most significant changes are the collapse of the Soviet Union in the early 1990s and the more recent rise of developing countries as energy importers. Non-Organization for Economic Cooperation and Development (OECD) countries have seen their share in worldwide energy demand rise from less than $30 \%$ in 1970 to almost $60 \%$ in 2014 (BP, 2015; see also Fig. 1). Some of the world's biggest energy importers (for example, China, India) are outside of any meaningful institutional apparatus for energy governance. This has vast consequences: the IEA's ability to manage oil supply crises is largely dependent on its ability to affect world oil markets through releases from the IEA member's strategic reserves. In the 1970 s, all of the major oil importing countries were members of the OECD; today, rapidly developing countries have changed the landscape. For instance, in 1995 China was importing roughly 400,000 barrels of crude oil per day; 

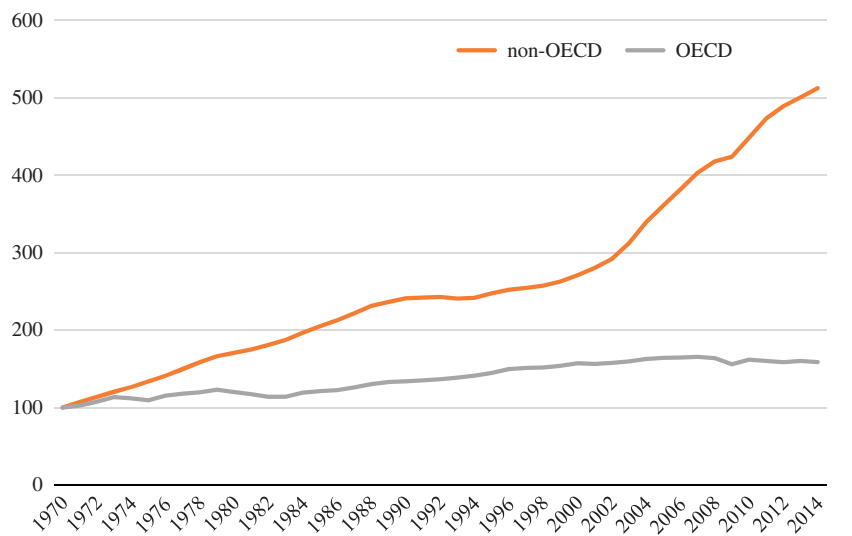

Figure 1 | OECD and non-OECD primary energy consumption, 1970-2014 $(1970=100)$.

Source: BP (2015).

in 2014, it was importing 6.2 million barrels per day-more than France and Italy combined (BP, 2015). With major oil customers operating outside of the IEA framework, the organization's members could be left with significantly less control over the oil market in the event of a crisis. Consequently, the IEA has been urged to expand its membership to include China and India, but there are significant obstacles to such an expansion (Colgan, 2009; Van de Graaf, 2015).

A third major transition is the increasing volatility on oil and gas markets, even in the absence of changes linked to climate change. Oil prices have swung markedly over the past few years. The period 2005-2014 witnessed a cycle of high (and volatile) energy prices, after a long cycle of low prices in the period 19852005 (see Fig. 2). High oil prices in the 2000s spawned an active debate about "peak oil" and the amount of oil geologically available on the planet. The revolution in shale gas and tight oil production in North America has largely stymied this debate. There are opposing views of the current situation. Some observers, such as Rex Tillerson (2013), the chairman and CEO of ExxonMobil, avow that "we are now witnessing the transition to a new Era of Abundance". Others, such as Klare (2009), see the fracking revolution as a sign that we are entering the "Era of Extreme Energy". In Klare's view, shale gas, tight oil, the Arctic race and tar sands are all symptoms showing it is getting harder and more expensive to find new oil deposits. Tillerson and Klare both raise points with some validity, but regardless, it is already clear that the cheapest oil reserves are increasingly being produced from autocratic and sometimes politically unstable regions of the world. Since oil is traded on a globally integrated market, developments anywhere could provoke ripple effects throughout the world market. In that regard it is notable that the nature of threats to energy security has changed over time. In the 1970s, Arab nationalism and tight oil market conditions combined to make oil embargos from Organization of the Petroleum-Exporting Countries (OPEC) the dominant energy supply concern for energy-importing countries. In 2015, the nature of the threats has changed considerably. The role of nonstate actors has increased, in the form of piracy off the coast of Somalia, "bunkering" (that is, theft and smuggling) in Nigeria, and terrorism in Saudi Arabia, Syria and Iraq.

Scope and objectives of GEG. These trends and transformations highlight-and in some cases exacerbate-a host of externalities associated with our global energy system. These externalities include the possibility of national and international energy shortages, nuclear proliferation and global climate change.

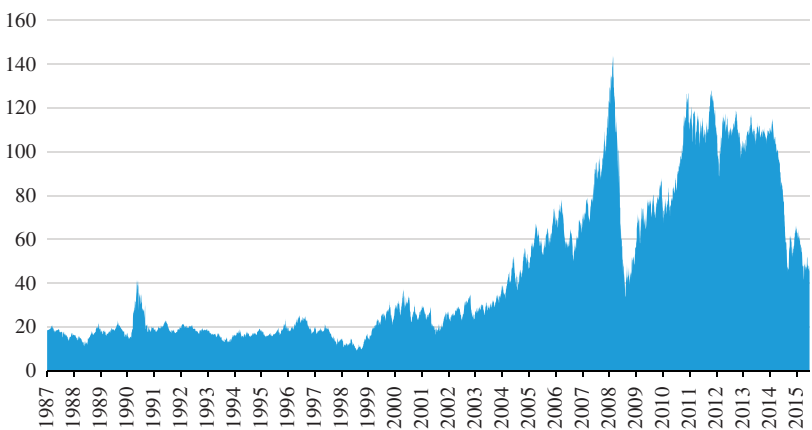

Figure 2 | Oil price, 1987-2015 (dollars per barrel, Europe Brent Spot Price FOB).

Source: U.S. Energy Information Administration: http://www.eia.gov.

Market price signals alone are often insufficient to provide satisfactory outcomes, creating a rationale for some form of governance to deal with those externalities (Meyer, 2012; Van de Graaf, 2013b). The concept of governance became widely used in development policy circles in the 1980s and, from there, also spread to other social science disciplines, including political science, law, public administration, economics, sociology, geography and history (Rhodes, 1996). The emergence and rapid spread of the term is linked to processes of neo-liberalism and globalization, which denotes the global shift from the 1970s onwards to financial deregulation, trade liberalization and the consolidation of global production networks (Scholte, 2005). These shifts are said to have eroded the capacity of traditional modes of statebased regulation to steer society, both domestically and internationally (Strange, 1996). Other scholars, however, have documented that the "shift" towards non-state forms of governance is often exaggerated and that such forms actually have a long history (Green and Colgan, 2013).

Although the "retreat of the state" is probably overstated in many narratives of globalization, there is plentiful evidence that non-state actors have come to play a more important role in issues of public policy. Where governance was once assumed to be synonymous with the activities of government, today it is understood to also encompass the activities of local and international non-governmental organizations (NGOs) and activist groups, and the decisions crafted in corporate boardrooms and at global conferences. The key difference between "government" and "governance" is of course that the former exercises formal authority, backed by strong enforcement mechanisms, whereas the latter refers to activities backed by shared goals that may or may not rely on formal authority and coercive power (Rosenau and Czempiel, 1992).

Against this background, a number of scholars have set out to examine the scope and rationale of GEG. Florini and Sovacool (2009: 5239) define GEG as the "international collective efforts undertaken to manage and distribute energy resources and provide energy services". Yet, the scope of GEG is not well defined. The potential scope of GEG is any social, political or economic issue that (1) crosses international borders and (2) is tightly connected to the production, distribution or consumption of energy. The actual scope is the set of issues to which attention is actively being paid by a set of relevant actors, including states and/or existing international organizations. Understanding the gap between the potential and actual scope of GEG is crucial for understanding how the existing set of energy institutions might evolve in the future. For policymakers, the gaps between potential and actual institutions highlight the leverage points where effective change might be made.

The potential scope of GEG contains at least five major objectives (Dubash and Florini, 2011; Goldthau, 2013), as depicted 


\begin{tabular}{|c|c|}
\hline Goal & Associated activities \\
\hline $\begin{array}{l}\text { 1. Security of energy supply and } \\
\text { demand }\end{array}$ & $\begin{array}{l}\text { - Managing petroleum reserves to buffer energy shocks (for example, coordinating releases from the IEA member states' } \\
\text { strategic petroleum reserves) } \\
\text { - Energy market information sharing (for example, Joint Organizations Data Initiative) and analysis (for example, World } \\
\text { Energy Outlook) } \\
\text { - Addressing pipeline politics and transit route disputes (for example, Russia-Ukraine gas disputes) } \\
\text { - Managing long-term investment issues }\end{array}$ \\
\hline 2. Economic development & $\begin{array}{l}\text { - Reducing energy poverty (for example, rural electrification programmes) } \\
\text { - Facilitating technology transfer and cooperation (for example, energy efficiency programmes, nuclear technology } \\
\text { sharing) } \\
\text { - Managing long-term investment profitability and macroeconomic stability }\end{array}$ \\
\hline 3. International security & $\begin{array}{l}\text { - Reducing the risk of nuclear proliferation, nuclear terrorism and civilian nuclear accidents } \\
\text { - Addressing the links between oil, international arms purchases and warfare } \\
\text { - Addressing sea piracy that targets oil and natural gas tankers } \\
\text { - Reducing and mitigating terrorist attacks on pipelines and energy infrastructure (including cyberattacks) }\end{array}$ \\
\hline 4. Environmental sustainability & $\begin{array}{l}\text { - Facilitating cooperation on global climate change } \\
\text { - Developing renewable energy sources, markets and regulations } \\
\text { - Managing national and regional pollution deriving from energy production } \\
\text { - Facilitating carbon pricing policies }\end{array}$ \\
\hline 5. Domestic good governance & $\begin{array}{l}\text { - Addressing human rights violations associated with extractive industries } \\
\text { - Helping governments adopt rational, best-practices in regulation } \\
\text { - Encouraging transparency in energy markets and governance }\end{array}$ \\
\hline
\end{tabular}

in Table 1. These objectives are pursued, to varying degrees, by international organizations in conjunction with state and nonstate actors.

These objectives form a part of GEG because they are associated with transboundary issues in one of three ways (Florini and Sovacool, 2009; Lesage et al., 2010a; Van de Graaf, 2013b; Karlsson-Vinkhuyzen, 2015). First, some objectives, like managing global climate change or nuclear terrorism, clearly relate to the cross-border externalities of energy production and use. They exhibit global public goods characteristics and hence require action beyond the national level to avoid the collective action dilemmas associated with such goods (Karlsson-Vinkhuyzen et al., 2012). Second, other objectives, such as protecting human rights or reducing energy poverty, principally relate to individuals within national borders, but elicit concern and problem-solving (or problem-causing) action from international sources (Ghosh and Ganesan, 2015). Third, some objectives are international because states use international institutions to learn from, and/or cajole, each other to make changes to their domestic governance. Thus domestic good governance fits in the scope of GEG to the extent that actors seek to use international energy institutions to "reach in" to areas of traditional sovereignty, typically in noncoercive ways such as best-practice sharing and information dissemination.

One branch of the GEG literature conceptualizes the key energy challenges such as externalities (climate change), transparency issues (oil price volatility) or market asymmetries (for example, National Oil Companies) in terms of global market failure. This creates a need, not for global governance as defined above, but more specifically for global (public) policy-thus embedding the whole debate in a growing academic conversation on "global policy" in sectors as diverse as trade, health, climate or technology (Goldthau, 2013).

In spite of the global benefits to be reaped from international cooperation, states have traditionally regarded the energy sector as a crucial component of national sovereignty. This means that, in effect, national energy governance still reigns above regional or GEG. Even in the European Union (EU), by far the world's most advanced experiment with regional integration, the member states have vigilantly guarded their sovereign prerogatives with regard to energy policy. The result is what McGowan (2009: 21) has called a "paradox of sovereignty", whereby states have less control over energy policy-due to the globalization of energy markets and related externalities-but remain largely unwilling to act jointly.

\section{Mapping the global energy architecture}

A key strand in the literature has been, and still is, concerned with mapping the global energy architecture. As ElBaradei (2008), former director-general of the International Atomic Energy Agency (IAEA), observed in 2008: "We have a World Health Organisation, two global food agencies, the Bretton Woods financial institutions and organisations to deal with everything from trade to civil aviation and maritime affairs. Energy, the motor of development and economic growth, is a glaring exception". Starting from this observation, a large number of scholars have addressed the question: "who governs energy?" (Florini and Sovacool, 2009). ${ }^{4}$ This is no easy question to answer. Various mapping exercises have ensued and they have all come up with a different set of institutional arrangements.

Box 1 offers a summary of the results of eight different efforts to map GEG arrangements and institutions. The results are strikingly different. The number of "global energy governors" identified ranges from 6 (Kérébel and Keppler, 2009) to 50 (Sovacool and Florini, 2012). Such mapping exercises of course depend very much on how wide the net is cast. Some of these studies focus exclusively on oil and gas markets (Kérébel and Keppler, 2009), others on renewable energy sources and low-carbon technologies (Suding and Lempp, 2007; see also Barnsley and Ahn, 2014; Roehrkasten, 2015). Some focus exclusively on intergovernmental organizations and summit processes (for example, Colgan et al., 2012; Wilson, 2015), others also include international NGOs, multilateral financial institutions and hybrid entities, involving everything from transnational networks of advocacy to quasiregulatory private bodies, global policy networks and publicprivate partnerships (Sovacool and Florini, 2012). 
- Suding and Lempp (2007): UN Commission on Sustainable Development (UN-CSD), United Nations Department on Economic and Social Affairs (UN-DESA), United Nations Environment Programme (UNEP), IEA, Asia-Pacific Partnership on Clean Development and Climate (APP), Global Bioenergy Partnership (GBEP), Global Village Energy Project (GVEP), Johannesburg Renewable Energy Coalition (JREC), Mediterranean Renewable Energy Programme (MEDREP), IEA's Networks of Expertise in Energy Technology (NEET), Partnership for Clean Indoor Air (PCIA), Renewable Energy and Energy Efficiency Partnership (REEEP), Global Network on Energy for Sustainable Development (GNESD), International Science Panel on Renewable Energies (ISPRE), European Renewable Energy Council (EREC), International Renewable Energy Agency (IRENA), Society for Solar Energy (ISES), World Council for Renewable Energy (WCRE), G8

- Kérébel and Keppler (2009): World Energy Council (WEC), OPEC, IEA, IEF, EITI, Jeddah Energy Summit

- Lesage et al. (2010a): World Bank Group, UN-CSD, IAEA, IEF, UNFCCC, IRENA, G8, Nuclear Energy Agency (NEA), OPEC, IEA, Gas-Exporting Countries Forum (GECF), International Partnership for Energy Efficiency Cooperation (IPEEC), AsiaPacific Economic Cooperation (APEC), Organización Latinoamericana de Energía (OLADE), Energy Charter Treaty (ECT), African Energy Commission (AFREC)

- Sovacool and Florini (2012): UN, Global Environment Facility (GEF), IEA, OLADE, ECT, Organization for Economic CoOperation and Development (OECD), International Renewable Energy Agency (IRENA), Generation IV International Forum (GIF), OPEC, GECF, IEF, International Partnership for the Hydrogen Economy (IPHE), G8, Summit of the Americas, WEC, World Council for Renewable Energies (WCRE), Global Energy Network Institute (GENI), Asian Development Bank (ADB), World Bank Group, European Bank for Reconstruction and Development (EBRD), African Development Bank (AfDB), InterAmerican Development Bank (IDB), International Fund for Agricultural Development (IFAD), Association of Southeast Asian Nations (ASEAN), European Union (EU), Organization of the Black Sea Economic Cooperation (BSEC), Shanghai Cooperation Organization (SCO), Southern African Development Community (SADC), APEC, South Asian Association for Regional Cooperation (SAARC), Central Asia Regional Economic Cooperation (CAREC), REEEP, GNESD, International Network on Gender and Sustainable Energy (ENERGIA), Appropriate Infrastructure Development Group (AIDG), International Network for Sustainable Energy (INFORSE), World Business Council on Sustainable Development (WBCSD), Collaborative Labelling and Appliance Standards Programme (CLASP), Efficient Energy for Sustainable Development Partnership (EESD), GVEP, International Institute for Energy Conservation (IIEC), Partnership for Clean Fuels and Vehicles (PCFV), Clinton Climate Initiative (CCI), Energy Through Enterprise (E+Co), Global Energy Efficiency and Renewable Energy Fund (GEEREF), SmallScale Sustainable Infrastructure Development Fund (S3IDF), Solar Electric Light Fund (SELF), Acumen Fund (AF), Global Alliance for Clean Cookstoves (GACC), Green Climate Fund (GCF)

- Colgan et al. (2012): IAEA, OPEC, OECD, OAPEC, OLADE, IEA, G7, IEF, ECT, IRENA, IPEEC

- Leal-Arcas and Filis (2013): UN, EU/EEA, NAFTA, ASEAN/AFTA, ECC, GECF, G8, G20, IEA, MEF, OPEC, UNFCCC, WPC, OPEC

- Wilson (2015): OPEC, IEA, ECT, IEF, GECF, APEC, EAS, WTO, G8, G20

- Escribano (2015): EITI, GECF, IAEA, IEA, IEF, IPEEC, JODI, NEA, OAPEC, OPEC, SE4ALL

A group of scholars has started to conceptualize this patchwork of institutions as a single organism, a "regime complex", and have assessed how it has behaved over time (Colgan et al., 2012; Baccini et al., 2013; Van de Graaf, 2013b), thus moving from static to dynamic snapshots of the global energy architecture. The concept of a "regime complex" was coined by Raustiala and Victor (2004) to refer to the "array of partially overlapping and non-hierarchical institutions governing a particular issue area”. The term is akin to Biermann et al.'s (2009) concept of a "global governance architecture", which they define as "the overarching system of public and private institutions that are valid or active in a given issue area of world politics".

Confronted with such an alphabet soup, some scholars have judged that "no single account can do justice to the multiplicity of rules and institutions that make up the full energy regime complex" (Colgan et al., 2012). Florini and Sovacool (2009) have circumvented the issue by listing the "types" of energy governors, rather than presenting an exhaustive list. Cherp et al. (2011) take a different approach by listing some actors and organizations within three GEG arenas: energy security, energy access and climate change. This links to broader discussions about the difficulty to map regime complexes in general-a nice illustration is the very different mapping of the climate change regime complex provided by Keohane and Victor (2011), on the one hand, and Abbott (2012), on the other.
Key international organizations. A notable number of studies have been concerned with studying individual institutions and their role in GEG. The Paris-based IEA, a daughter organization of the OECD, has received by far the most attention in this regard. It is generally regarded as the "world's foremost multilateral energy organization" (Van de Graaf, 2015) and "the closest we have to a World Energy Organization" (Van de Graaf, 2013a). It should thus not come as a surprise that the IEA's evolving role and governance functions has received ample attention, both in the 1970s and 1980s and in recent years (Van de Graaf and Lesage, 2009; Colgan, 2009; Leverett, 2010; Kohl, 2010; Van de Graaf, 2012, 2015; Lesage and Van de Graaf, 2013; Heubaum and Biermann, 2015; Colgan and Van de Graaf, 2015).

The IEA's counterpart on the global oil market, OPEC, has probably received more attention but not in relation to GEG (for an exception, see Goldthau and Witte, 2011). Most of the literature on OPEC has tried to model its behaviour as a would-be commodity cartel, and tried to examine the influence of the organization on world oil prices. While this literature is marked by a lot of disagreement, recent research demonstrates that OPEC members cheat on their agreed production quotas most of the time and that the organization does not have the capacity at all to set world oil prices, although this belief persists as a "rational myth" (Colgan, 2014). 
Another key institution, sometimes missed by the GEG literature because of the agency's orientation towards security issues, is the IAEA. Set up within the United Nations in 1957, the IAEA's objective is to promote safe, secure and peaceful nuclear technologies (Lesage et al., 2010a, b). Its programme of work includes three areas: safeguards and verification (to ensure that activities are not used for military purposes); safety and security (to protect people and the environment from radiation); and science and technology (to mobilize peaceful applications of nuclear technology). The role of civilian nuclear energy in international security questions has recently attracted scholarly attention (Fuhrmann, 2012; Brown and Kaplow, 2014).

Other international institutions that have received some attention in the literature on GEG include the G8 and G20 (Lesage et al., 2009, 2010a; Van de Graaf and Westphal, 2011; Downie, 2015a), IRENA (Van de Graaf, 2013a, b; Urpelainen and Van de Graaf, 2013), the UN (Karlsson-Vinkhuyzen, 2010), the International Energy Forum (IEF) (Fattouh and van der Linde, 2011), the International Partnership for Energy Efficiency Cooperation (IPEEC) (Lesage et al., 2010b), the Energy Charter Treaty (ECT) (Konoplyanik and Walde, 2006; Aalto, 2016), the Energy Community Treaty (Renner, 2009), various multilateral development banks (Nakhooda, 2011; Kim and Urpelainen, 2013) and international financial institutions (Newell, 2011), among others. Last but not least, the EU has an explicitly regional energy governance approach (based on liberalization), which it also tries to export to non-EU countries and to the global stage (Goldthau and Sitter, 2015).

Private actors and transnational governance. Beyond studying international energy organizations created by states, scholars have also turned their attention to the roles played by non-state actors such as business, civil society and science organizations in GEG. These non-state actors sometimes participate in intergovernmental processes. The December 2015 climate conference in Paris, for instance, was attended by a large number of civil society and business groups, who all tried to influence the negotiation process. Yet, non-state actors have also established networks whose defining characteristic is independent of state approval or support. Where such networks become institutionalized and begin to set broader norms and rules, they become transnational governance networks in their own right (Biermann and Pattberg, 2012; Green, 2013).

Such transnational governance networks come in various forms. Some are structured as "public-private partnerships", bringing together corporations, societal groups and governments around global policy objectives. A case in point is the REEEP, a multi-stakeholder platform to pursue cooperation in the area of renewable energy and energy efficiency. Another instance of transnational governance are "private regimes", which involve non-state actors willing to commit to self-regulatory norms, standards and certification schemes in a given issue area. The Extractive Industries Transparency Initiative (EITI), which aims to tackle corruption and graft in the upstream oil and gas sectors by facilitating voluntary disclosing of payments, is a case in point (Haufler, 2010). The EITI is part of a broader wave of information-based governance schemes in global energy and climate governance (Florini and Saleem, 2011).

Given the enormous diversity in such transnational governance networks, it need not come as a surprise that there is equally much divergence in the effectiveness of such networks. Szulecki et al. (2011) found that, so far, the majority of private-public energy partnerships have not been fulfilling the high expectations placed on their effectiveness. Nevertheless, research by de Coninck et al. (2008) has concluded that international technology-oriented agreements to address climate change can be effective, especially if they set standards and mandates for specific sectors, not for specific technologies.

A minority of scholars has focused not on institutions or on transnational networks, but on less tangible aspects of GEG such as norms (for example, Gillies, 2010) and corporate elite ties in global energy (de Graaff, 2012).

Domestic-international interactions. The description provided in this section focuses on international organizations and networks, but GEG is formed by an interaction between international, national and subnational actors. The interactions between the actors are complex and characterized by multiple points of contact. For instance, the IEA works with its member states to improve good governance and share best practices of energy policies. In practice, this means that the IEA interacts with multiple branches of the national governance. In the United States, the IEA frequently works with the Department of Energy, Congress and various House and Senate committees, the Federal Energy Regulatory Commission and the State Department. Further, the activity and influence of the international actors depends significantly on the issue at hand. International organizations often have only an indirect influence on issues that lie firmly within national jurisdictions, such as electrical grid infrastructure or taxation policy. Many questions about the nature and efficacy of the international-national interfaces of energy governance remain unanswered.

\section{Evaluating GEG}

Over time, GEG scholars have moved beyond purely mapping the global energy architecture to an evaluation and interpretation of it. Many argue that the current global energy architecture needs reform, but the reasons for and substance of that reform is subject to more controversy. Some have proposed to create an entirely new Global Energy Agency (ElBaradei, 2008; Akinola, 2013), although a large majority of authors has strongly advised against it, deeming it both undesirable and unfeasible. In the words of Lesage et al. (2010a: 7-8): "How could the General Assembly arrive at a timely and substantial agreement, when we take into account its bureaucratic habits, the enormous diversity in preferences, the risk of free-riding behavior and, last but not least, the distrust of a lot of capitals vis-à-vis the UN for dealing with delicate and strategic issues like energy?".

In this section, we make two assessments of the global energy architecture. One is a functional gap analysis, based on the five overarching goals of GEG identified earlier. The other is an analysis of the legitimacy-efficacy trade-off in GEG. Here we thus move beyond a mere review of the existing GEG literature to add a perspective that has, in our view, been largely missing from the existing debates: What are the benchmarks against which one can assess the performance and pathologies of current efforts to govern energy?

Gap analysis of the regime complex for energy. Historically, the regime complex for energy has grown for multiple reasons (Colgan et al., 2012). Some institutions were created as a response to energy crises, such as the creation of the IEA in 1974 in the aftermath of the Arab oil embargo. Other institutions, such as the IEF, were created out of a desire to bridge multiple worldviews and different understandings of the global energy market. ${ }^{5}$ As the regime complex grows, it is worth considering the extent to which the current regime complex addresses the potential scope of GEG.

Figure 3 provides a rough mapping of the activities of some of the largest institutions within the regime complex for energy. The activities are mapped against the five objectives identified earlier. Three caveats are in order: first, the figure says nothing about the 
IEA OPEC IAEA IRENA IEF WB WTO UNFCCC EITI

\begin{tabular}{lccccccc}
\hline Energy security & $\checkmark$ & $\checkmark$ & $\checkmark$ & $\checkmark$ & $\checkmark$ & $\checkmark$ & \\
$\begin{array}{l}\text { Economic } \\
\text { Development }\end{array}$ & $\checkmark$ & $\checkmark$ & & & $\checkmark$ & $\checkmark$ & $\checkmark$ \\
$\begin{array}{l}\text { International } \\
\text { Security }\end{array}$ & & & $\checkmark$ & & & & \\
Environment & $\checkmark$ & & $\checkmark$ & $\checkmark$ & & $\checkmark$ & \\
$\begin{array}{l}\text { Domestic good } \\
\text { governance }\end{array}$ & $\checkmark$ & & & & & & \\
\end{tabular}

Figure 3 | Mapping institutional activities of GEG.

efficacy of those activities. For instance, the IEA, IRENA and the World Bank are all working on the issue of climate change, but there are real questions about the efficacy of those activities. Second, the figure captures only the major foci of the institutions' activities. Third, there is considerable heterogeneity in the activities associated with each objective. For instance, while the IEA and EITI both work on domestic good governance, the IEA works primarily to assist developed countries to craft more rational economic policies (for example, electrical-grid best practices), whereas EITI focuses on the transparency of resource rents in energy-exporting countries in the developing world.

As Fig. 3 suggests, clearly there are gaps between the potential and actual scope of GEG. Some objectives, like energy security, receive a great deal of institutional attention. Fewer organizations are focused on other objectives, such as international security or domestic good governance. Moreover, institutions have quite different concerns within the broad objectives. For instance, while the IEA is concerned about the supply of oil and energy, OPEC is focused on security of demand, and IRENA is focused on alternatives to the oil market altogether. Another example lies in economic development: while the IEA is concerned about macroeconomic impacts of energy for the OECD states, the World Bank and other multilateral development banks aim to reduce energy poverty in the developing countries.

Table 2 highlights a key governance gap associated with each of the five objectives. With regard to energy security, international dispute resolution has become a major concern for many states, whether they are exporting, importing or transit countries. The need for dispute resolution is perhaps most vividly demonstrated in the conflicts between Russia and the Ukraine over natural gas transit services, or between Exxon and Venezuela over alleged asset expropriation. For economic development, the issue of energy poverty is enormous: currently 1.3 billion people lack access to electricity and 2.6 billion people lack access to modern fuels for cooking and heating. ${ }^{6}$ Environmentally, the regime complex for energy is attempting to provide responses to global climate change, but much more substantial action is needed.

There are two areas where the gap between the actual and potential scope of GEG is especially noticeable. The first is the link between oil and international security. There is now a considerable body of academic literature that argues that oil has a causal effect on the incidence of civil wars in oil-producing countries (Fearon and Laitin, 2003; Collier and Hoeffler, 2004; LeBillon, 2005; Ross, 2012; Barma, 2014; Colgan, 2015). ${ }^{7}$ More recent research indicates that oil is also causally linked to international conflicts, particularly when oil income is available to revolutionary governments in countries like Libya, Iran, Iraq and Venezuela (Colgan, 2010; Colgan, 2013a, b). Petrostates were involved in $22 \%$ of all militarized interstate disputes since 1970 , even though they are just 31 states and a small fraction of the world's population. Overall, scholarly work suggests that the international trade of oil injects vast amounts of money into political systems that are ill-suited to receive it, with significant consequences for the centralization of political power and the

\begin{tabular}{|ll|}
\hline Table $\mathbf{2}$ | Key gaps in GEG \\
Objective & Key gap in governance \\
\hline Energy security & $\begin{array}{l}\text { Dispute resolution, especially for energy } \\
\text { transit issues }\end{array}$ \\
$\begin{array}{ll}\text { Economic development } & \text { Energy poverty in developing countries } \\
\text { International security } & \begin{array}{l}\text { Conflicts and arms purchases from } \\
\text { petrodollars }\end{array} \\
\text { Environment } & \begin{array}{l}\text { Developing meaningful responses to climate } \\
\text { change }\end{array} \\
\text { No real buy-in for EITI-like principles of } \\
\text { transparency, human rights }\end{array}$ \\
\hline
\end{tabular}

build-up of military capability in oil-exporting states. These facts raise a host of political, economic and moral questions about the world's continued dependence on petroleum as a primary source of energy in advanced economies. Indeed, given that oil income plays a causal role in international and civil wars, policymakers may find it desirable to minimize the flow of such income into under-institutionalized states, or to limit their access to international arms markets. Yet at present the regime complex for energy has no real institutional capacity for addressing these issues.

The second critical gap in the regime complex is in the protection of human rights in the developing world. While a number of institutions, such as the World Bank, at least discuss this topic, human rights issues are characterized by a lack of governance. This is perhaps most evident in Nigeria, Angola, Sudan and other African nations where foreign multinational oil companies operate to extract oil for export sales. Shell Oil, for example, suffered widespread condemnation for its alleged connection to Nigerian troops who committed serious abuses in the course of protecting Shell personnel and equipment. International condemnation of Shell exploded in 1995, when Nigeria executed the noted author Ken Saro-Wiwa and eight Ogoni colleagues who had been campaigning against the devastation of the Niger Delta (Frynas, 2003). Despite the bad press and occasional calls for more rigorous governance, the oil industry has not seen an analogue to the Kimberley Process, a certification scheme to prevent "blood diamonds"-rough diamonds used by rebel movements to finance wars-to enter international trade. ${ }^{8}$ There exists no parallel certification scheme with respect to "blood oil" (Weinar, 2016), an omission that is painfully relevant in light of the large oil revenues generated by Islamic State in Syria. ${ }^{9}$

Legitimacy and efficacy in the energy regime complex. The relationship between legitimacy and efficacy provides another lens that can be helpful in assessing the regime complex for energy. Efficacy refers to the extent to which an institution achieves the desired outcomes associated with its activities, and the extent to which those outcomes match the larger objectives. Legitimacy is more complicated, and can be conceptualized in multiple ways. Two paired definitions of legitimacy are especially useful: sociological versus normative legitimacy, and input versus output legitimacy. An institution is sociologically legitimate when it is accepted as appropriate, and worthy of being obeyed, by relevant audiences. An institution is normatively legitimate when its practices meet a set of standards that have been stated and defended, such as treating like cases alike (Buchanan and Keohane, 2006). An institution has input legitimacy on the basis of the actors that participated in the decision and the process used to create outcomes. An institution has output legitimacy based on effective problem-solving and the quality of its policy outcomes (Risse, 2004). 


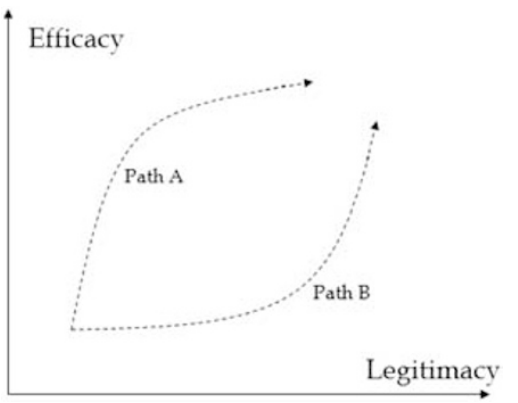

Figure 4 | Interaction between legitimacy and efficacy.

The development of the regime complex for energy is affected by the interaction between legitimacy and efficacy. An ideal regime complex would be constituted by institutions that were both legitimate and efficacious. Under some conditions, these qualities are partially conditional on each other: an institution can be made more efficacious by making it more legitimate, and vice versa. For example, one of the core missions of the IEA is to manage the risk of energy supply crises, especially oil price shocks. However, the IEA's efficaciousness in this task depends significantly on its market power and its ability to move global oil markets through coordinated releases from member states' strategic petroleum reserves (Colgan, 2009). As the global marketplace has changed, the role of energy importers outside of the IEA such as China and India has dramatically increased in importance. Yet China and India are reluctant to become members of the IEA, in part because they do not perceive the IEA as legitimate: they see it instead as a club for rich countries (Van de Graaf, 2015; Downie, 2015b). Thus the efficacy of the IEA is shaped by its perceived input and sociological legitimacy.

Strategies for improving the efficacy and legitimacy of international institutions will depend on the particular circumstances of the institution. To illustrate this point, Fig. 4 highlights two possible paths that an institution might take in improving its efficacy. One route (Path A) is to change the rules, functional tasks and capabilities of the institution itself to alter the range of outcomes the institution can achieve. As a consequence of this increase in efficacy, the institution could be perceived as more legitimate by relevant audiences (an example of output legitimacy), which in turn could increase the benefits of membership. An alternative route (Path B) is to first focus on the membership and input legitimacy of the institution, which could thereby increase its functional capability and thus efficacy. There is unlikely to be a single best path for all institutions at all times, and questions remain about the conditions under which one path is chosen rather than another.

\section{Conclusions and outlook}

The state of GEG. This article has reviewed the existing literature on GEG and added a critical assessment of the global energy regime complex, based on a functional gap analysis, on the one hand, and the relationship between efficacy and legitimacy, on the other.

Three broad lessons emerge from the analysis. The first is the most basic point of this article: there are significant gaps between the potential and actual scope of GEG. Even though there is no shortage of international institutions, forums and networks that address various aspects of GEG (see Box 1), these governance arrangements fall way short in addressing major energy-related externalities and delivering the overarching goals of GEG (as identified in Table 1).

\section{Table 3 | Key cleavages for objectives of GEG}

\begin{tabular}{|ll} 
Objective & Key cleavages \\
\hline Energy security & Exporting, importing and transit states \\
Economic development & Developed and developing states \\
International security & Varies \\
Environment & Developed and developing states \\
Good governance & Oil corporations, producer states and \\
& international civil society \\
\hline
\end{tabular}

The second lesson is that the "core" of the regime complex depends significantly on which objective(s) are at issue. Suppose the regime complex is pictured as institutions that lie within concentric circles, with some institutions closer to the core than others. If one focuses primarily on the objective of energy security, institutions such as OPEC and the IEA lie at the core of the regime complex. If instead one focuses on the environmental or development impact of energy, institutions like IRENA and the UNFCCC or the World Bank become far more central. As such, there is no single core to the complex; instead, there are multiple cores around which organizations cluster based on their objectives and activities.

The third lesson is that while some of these gaps exist simply due to inaction or an absence of political will, many of these gaps exist because of genuine differences in the national interests of different types of states. Table 3 suggests some of the key cleavages between different types of states, depending on the objective selected. ${ }^{10}$ For example, on the issue of energy security, producers are understandably concerned about the security of demand and ensuring a profitable rate of return on their investments, while suppliers focus on the security of supply for as a basic input to an advanced industrial economy. In the area of economic development, the primary concerns of developed states (for example, macroeconomic stability) are likely to be different from those of developing states (for example, energy poverty). Some of these differences are a matter of the priority of objectives; in other cases, there are real differences in states' preferences for outcomes (for example, high or low oil prices). These differences in state interests can and do limit international cooperation. Policymakers seeking to design institutions are likely to be successful to the extent that they respect the differences in state interests, and work within the areas where state interests overlap.

What Table 3 does not do, however, is offer a comprehensive analysis of how governance mechanisms emerge, or how and why gaps appear within the regime complex. One can expect that states construct international regimes on the basis of their interests, which in turn reflect the interests of the major constituencies that exert influence over state leaders (Keohane, 1989). This observation opens at least two kinds of research questions. First: who, how and under what conditions are subnational actors able to influence state preferences for GEG? Second: given a particular issue area, who, how and under what conditions do states and other international actors design institutions for GEG? Identifying the causes and consequences of governance gaps is a major research challenge.

Recent trends and innovations in GEG. Beyond the three energy transitions identified above, the energy sector is continuously upended by rapid changes, including innovations at the multilateral level. At their 2014 meeting in Brisbane, for example, the G20 leaders agreed on a set of Principles on Energy Collaboration, in which they recognized that "the international energy architecture needs to reflect better the changing realities of the world energy landscape" (G20, 2014). In June 2015, the leaders of 


\section{Box 2 | Targets under the seventh Sustainable Development Goal}

\section{1}

By 2030, ensure universal access to affordable, reliable and modern energy services

7.2

By 2030 , increase substantially the share of renewable energy in the global energy mix

7.3

By 2030, double the global rate of improvement in energy efficiency 7.a

By 2030, enhance international cooperation to facilitate access to clean energy research and technology, including renewable energy, energy efficiency and advanced and cleaner fossil-fuel technology, and promote investment in energy infrastructure and clean energy technology

7.b

By 2030, expand infrastructure and upgrade technology for supplying modern and sustainable energy services for all in developing countries, in particular least developed countries, small island developing States and land-locked developing countries, in accordance with their respective programmes of support

the G7, for the first time, pledged to fully decarbonize their economies by the end of this century. In September 2015, the United Nations adopted a set of Sustainable Development Goals, which include a specific goal to "ensure access to affordable, reliable, sustainable and modern energy for all” by 2030 (see Box 2). And, in the run-up to the COP21 climate conference in Paris, in December 2015, more than 160 countries submitted national plans on how they intend to contribute to the goals of the climate change convention in the post-2020 period.

Important changes are also afoot in the area of energy trade and investment governance. In an effort to revive the ECT, much in disarray after Russia's withdrawal in 2009, no less than 64 states (including China) signed a new International Energy Charter in May 2015 (Aalto, 2016), though its actual effectiveness remains to be seen. In July 2014, 14 WTO members (including the United States, EU, China and Japan) launched plurilateral negotiations for an Environmental Goods Agreement with an aim to reduce trade barriers for goods such as wind turbines and solar panels, most relevant in an era of growing green energy trade conflicts (Lewis, 2014). The recently concluded trade agreement between the United States and some Pacific Rim countries (Trans-Pacific Partnership), as well as the Transatlantic Trade and Investment Partnership, still under negotiation, could have important consequences on the energy front. The Chinesesponsored Asian Infrastructure Investment Bank could also become an important component of the energy regime complex.

Of course, GEG is not the exclusive terrain of multilateral agreements and institutions. National regulations can sometimes reverberate globally. Such is the case with the recent US rules (Dodd-Frank Act from 2010) and EU rules (Transparency Directive from 2013) requiring mandatory disclosure of payments made by companies engaged in the oil, gas, mining and logging sectors. These rules are supposed to complement the (voluntary) EITI. Given that they are issued by the EU and the United States, they are set to become the global standard. Domestic and international courts are also an oft-overlooked player in global energy politics. In March 2015, for instance, the International Court of Justice upheld a prior ruling by an Ecuadorian court that fined the US oil company Chevron US\$9.5 billion in 2011 for polluting parts of the Amazon. In a landmark ruling in June 2015, a domestic court in The Hague ordered the Dutch government to cut carbon emission to protect its citizens from climate change.

These changes take place against the background of rapidly evolving energy markets and technologies. The shale revolution, the Fukushima nuclear accident, the continuing decline in the cost of renewables and growing calls to divest from fossil fuels, which may become "stranded assets" in a carbon-constrained world, are all trends that have the potential to dramatically change the face of global energy markets. Geopolitical events such as the Ukraine crisis (and the ensuing energy sanctions against Russia), the continued unrest in the Middle East (Yemen, Syria and so on) or the build-up of tensions in the South China Sea are often linked to energy and contribute to the securitization of energy issues-thereby also impinging on the agenda and purposes of GEG.

The evolving research agenda. Given that these shifts and transitions are already under way, and that the gaps between the actual and potential scope of GEG are likely to persist in the future, current policymakers might consider the ways in which institutions can be created or extended to address contemporary issues. The purpose of this concluding section is not to provide a set of policy recommendations (for example, Hirst and Froggatt, 2012), but rather to highlight a variety of research questions for further exploration. While the research agenda of GEG is vast and continues to expand, we focus here on three areas where we see much promise in pursuing further research.

A first set of questions relates to the nature and impact of $G E G$ beyond multilateral organizations. Many if not most studies of GEG have focused on the formal, interstate forms of energy cooperation and specific multilateral organizations (for example, Colgan et al., 2012; Leal-Arcas et al., 2015). Only a handful of scholars have moved to examine informal norms and practices in GEG (for example, Gillies, 2010; Florini and Saleem, 2011; Colgan and Van de Graaf, 2015). Even fewer scholars have ventured to examine the role of transnational or subnational players in GEG. The latter point is especially important with regard to issues such as mitigating the resource curse or expanding energy access in the global South, issues that exhibit both local and global facets (Carbonnier, 2011; Bazilian et al., 2014).

A second set of questions relates to the interplay between energy governance and related areas, in particular climate change (Fouquet, 2013; Heubaum and Biermann, 2015), water (Hussey and Pittock, 2012) and food security (Hendrix and Salehyan, 2012). The notion of a "resource nexus" captures the idea that these areas are all closely interconnected. Yet, in practice, scholars and practitioners still tend to depart from policy silos and fail to grasp the interactions between some of these sectors, and their governance implications (Florini and Sovacool, 2011). Looking beyond the confines of the energy policy silo, the trade-offs become much more complex than the traditional energy policy triangle of balancing energy security, energy access and climate mitigation (Gunningham, 2012). There is much to be learned from closer studies of the interactions between climate mitigation policies and fossil fuel markets (for example, van Asselt, 2014; Van de Graaf and Verbruggen, 2015), between biofuels and food security governance (Lima and Gupta, 2013) or between energy and water security.

A third promising area for further enquiry is to analyse global energy politics from the perspective of International Political Economy (IPE). The literature on energy politics is split between realist, geopolitical accounts about "energy security", on the one hand, and liberal, institutionalist accounts of "energy governance", on the other. By its focus on the interplay between states and markets at the international level, IPE has much to offer to study the rapidly changing world of energy. Yet, strikingly, energy has largely been ignored by IPE scholars and does not feature in the canonical textbooks. Recently, some scholars have launched a call to develop a genuine "IPE of 
energy" field of study (Kuzemko et al., 2012; Hancock and Vivoda, 2014; Van de Graaf et al., 2016).

Clearly, the research agenda for GEG includes a variety of issues that are both substantively important and theoretically challenging.

\section{Notes}

1 For information on this research project, see: http://old.gppi.net/focus_areas/global_ energy_governance/.

2 For information on this research project, see: http://lkyspp.nus.edu.sg/cag/research/ s-t-lee-project-on-global-governance.

3 It should be noted that these transitions do not exist in isolation but are closely intertwined. Rising energy demand from China, India and other emerging countries (which reflects rising living standards in those countries) has accelerated GHG emissions and energy security concerns.

4 This question paraphrases work by Avant et al. (2010): Who Governs the Globe?

5 It is noteworthy that the original supporters of the IEF, such as France, Venezuela and Norway, viewed the global market for energy as a potentially positive-sum game in which joint gains from cooperation were possible. Other countries, most notably the United States, were much more sceptical of this view, and historically tended to view the interaction between OPEC and the IEA as a zero-sum conflict.

6 IEA Website, http://www.iea.org/topics/energypoverty/ (visited September 2015).

7 The issue is debated, however: see, for example, Smith (2004).

8 In 2000, the United Kingdom and the United States initiated the Voluntary Principles on Security and Human Rights, a set of principles designed to guide companies in the extractive and energy sectors with respect to maintaining the safety and security of their operations while respecting human rights (see http://www.voluntaryprinciples. org). According to informed observers, however, the "Voluntary Principles appear to have faded into inactivity without ever developing a real institutional structure"

(Rose, 2015: 141)

9 There is of course the EITI, which we mentioned above and which was modelled to some extent after the Kimberley Process. Yet, the EITI is geared to tackle corruption and graft by developing a voluntary standard for disclosing payments in the extractive industries. It does not directly address human rights concerns.

10 We use the term cleavages to indicate policy areas of political contention.

\section{References}

Aalto P (2016) The new international energy charter: Instrumental or incremental progress in governance? Energy Research \& Social Science; 11(January): 92-96.

Abbott KW (2012) The transnational regime complex for climate change. Environment \& Planning C: Government \& Policy; 30 (4): 571-590.

Akinola O (2013) Global energy governance: Making a case for a world energy organization. Paterson Review of International Affairs; 13: 69-83.

Avant D, Finnemore M and Sell SK (2010) Who Governs the Globe? Cambridge University Press: Cambridge, UK.

Baccini L, Lenzi V and Thurner PW (2013) Global energy governance: Trade, infrastructure, and the diffusion of international organizations. International Interactions; 39 (2): 192-216.

Barma N (2014) The rentier state at work: Comparative experiences of the resource curse in East Asia and the Pacific. Asia of the Pacific Policy Studies; 1 (2): 257-272.

Barnsley I and Ahn SJ (2014) Mapping Multilateral Collaboration on Low-Carbon Energy Technologies. OECD/IEA: Paris, France.

Bazilian M, Nakhooda S and Van de Graaf T (2014) Energy governance and poverty. Energy Research \& Social Science; 1 (1): 217-225.

Biermann F and Pattberg P (2012) Global Environmental Governance Reconsidered. MIT Press: Cambridge, MA.

Biermann F, Pattberg P, van Asselt H and Zelli F (2009) The fragmentation of global governance architectures: A framework for analysis. Global Environmental Politics; 9 (4): 14-40.

British Petroleum (BP). (2015) Statistical review of world energy, http://www.bp .com/statisticalreview, accessed 1 December 2015.

Brown RL and Kaplow JM (2014) Talking peace, making weapons IAEA technical cooperation and nuclear proliferation. Journal of Conflict Resolution; 58 (3): $402-428$.

Buchanan A and Keohane RO (2006) The legitimacy of global governance institutions. Ethics \& International Affairs; 20 (4): 405-437.

Bull-Berg HJ (1985) United States international oil policy 1973-83: Pursuing a cooperative regime or an imposed order? Cooperation and Conflict; 20 (3): 173-194.

Carbonnier G (2011) Introduction: The global and local governance of extractive resources. Global Governance; 17 (2): 135-147.

Cherp A, Jewell J and Goldthau A (2011) Governing global energy: Systems, transitions, complexity. Global Policy; 2 (1): 75-88.

Colgan JD (2009) The International Energy Agency. GPPi Policy Paper Series, 6.
Colgan JD (2010) Oil and revolutionary government: Fuel for international conflict. International Organization; 64 (4): 661-694.

Colgan JD (2013a) Fueling the fire: Pathways from oil to war. International Security; 38 (2): 147-180.

Colgan JD (2013b) Petro-Aggression: When Oil Causes War. Cambridge University Press: New York, USA.

Colgan JD (2014) The emperor has no clothes: The limits of OPEC in the global oil market. International Organization; 68 (3): 599-632.

Colgan JD (2015) Oil, domestic conflict, and opportunities for democratization. Journal of Peace Research; 52 (1): 3-16.

Colgan JD and Van de Graaf T (2015) Mechanisms of informal governance: Evidence from the IEA. Journal of International Relations and Development; 18 (4): 455-481.

Colgan JD, Keohane RO and Van de Graaf T (2012) Punctuated equilibrium in the energy regime complex. The Review of International Organizations; 7 (2): 117-143.

Collier P and Hoeffler A (2004) Greed and Grievance in Civil War. Oxford University Press: Oxford.

Cowhey PF (1985) The Problems of Plenty: Energy Policy and International Politics. University of California Press: Berkeley, CA.

De Coninck H, Fischer C, Newell RG and Ueno T (2008) International technology-oriented agreements to address climate change. Energy Policy; 36 (1): 335-356.

De Graaff N (2012) Oil elite networks in a transforming global oil market. International Journal of Comparative Sociology; 53 (4): 257-297.

Downie C (2015a) Global energy governance in the G-20: States, coalitions, and crises. Global Governance; 21 (3): 475-492.

Downie C (2015b) Global energy governance: Do the BRICs have the energy to drive reform? International Affairs; 91 (4): 799-812.

Dubash N and Florini A (2011) Mapping global energy governance Global Policy; 2 (s1): 6-18.

Duffield J (2007) Over a Barrel: The Costs of U.S. Foreign Oil Dependence. Stanford Law and Politics: Stanford, CA.

ElBaradei M (2008) A global agency is needed for the energy crisis. Financial Times, 23 July.

Escribano G (2015) Fragmented energy governance and the provision of global public goods. Global Policy; 6 (2): 97-106.

Fattouh B and van der Linde C (2011) The International Energy Forum: Twenty Years of Producer-Consumer Dialogue in a Changing World. IEF: Riyadh, Saudi Arabia.

Fearon JD and Laitin DD (2003) Ethnicity, insurgency, and civil war. American Political Science Review; 97 (01): 75-90.

Florini A and Dubash N (2011) Introduction to the special issue: Governing energy in a fragmented world. Global Policy; 2 (s1): 1-5.

Florini A and Saleem S (2011) Information disclosure in global energy governance. Global Policy; 2 (s1): 144-154.

Florini A and Sovacool BK (2009) Who governs energy? The challenges facing global energy governance. Energy Policy; 37 (12): 5239-5248.

Florini A and Sovacool BK (2011) Bridging the gaps in global energy governance. Global Governance; 17 (1): 57-74.

Fouquet R (ed) (2013) Handbook on Energy and Climate Change. Edward Elgar: Cheltenham, UK.

Frynas JG (2003) Royal Dutch/Shell. New Political Economy; 8 (2): 275-285.

Fuhrmann M (2012) Atomic Assistance: How "Atoms for Peace" Programs Cause Nuclear Insecurity. Cornell University Press: Ithaca, NY.

G20 (2014) G20 Principles on Energy Collaboration. Brisbane Summit, 16 November.

Ghosh A and Ganesan K (2015) Rethink India's energy strategy. Nature; 521 (7551): 156-157.

Gillies A (2010) Reputational concerns and the emergence of oil sector transparency as an international norm. International Studies Quarterly; 54 (1): $103-126$.

Glaser C (2013) How oil influences U.S. national security. International Security; 38 (2): 112-146.

Goldthau A (ed) (2013) The Handbook of Global Energy Policy. John Wiley \& Sons: West Sussex, UK.

Goldthau A and Sitter N (2015) A Liberal Actor in a Realist World: The European Union Regulatory State and the Global Political Economy of Energy. Oxford University Press: Oxford, UK.

Goldthau A and Witte JM (2009) Back to the future or forward to the past? Strengthening markets and rules for effective global energy governance. International Affairs; 85 (2): 373-390.

Goldthau A and Witte JM (2011) Assessing OPEC's performance in global energy. Global Policy; 2 (s1): 31-39.

Goldthau A and Witte JM (eds) (2010) Global Energy Governance: The New Rules of the Game. Brookings Institution Press: Washington DC.

Green JF (2013) Rethinking Private Authority: Agents and Entrepreneurs in Global Environmental Governance. Princeton University Press: Princeton, USA 
Green JF and Colgan J (2013) Protecting sovereignty, protecting the planet: State delegation to international organizations and private actors in environmental politics. Governance; 26 (3): 473-497.

Gunningham N (2012) Confronting the challenge of energy governance. Transnational Environmental Law; 1 (1): 119-135.

Hancock K and Vivoda V (2014) International Political Economy: A field born of the OPEC crisis returns to its energy roots. Energy Research \& Social Science; 1 (1): 206-216.

Haufler V (2010) Disclosure as governance: The Extractive Industries Transparency Initiative and resource management in the developing world. Global Environmental Politics; 10 (3): 53-73.

Hendrix CS and Salehyan I (2012) Climate change, rainfall, and social conflict in Africa. Journal of Peace Research; 49 (1): 35-50.

Heubaum $\mathrm{H}$ and Biermann F (2015) Integrating global energy and climate governance: The changing role of the International Energy Agency. Energy Policy; 87: 229-239.

Hirst N and Froggatt A (2012) The reform of global energy governance. Grantham Institute for Climate Change, Discussion Paper No. 3.

Hughes L and Lipscy PY (2013) The politics of energy. Annual Review of Political Science; 16 (1): 449-469.

Hughes L and Long A (2015) Is there an oil weapon?: Security implications of changes in the structure of the international oil market. International Security; 39 (3): 152-189.

Hussey K and Pittock J (2012) The energy-water nexus: Managing the links between energy and water for a sustainable future. Ecology and Society; 17 (1): 31.

International Energy Agency (IEA). (2014) CO2 Emissions from Fuel Combustion: Highlights. OECD/IEA: Paris, France.

Kapstein EB (1990) The Insecure Alliance: Energy Crises and Western Politics Since 1944. Oxford University Press: Oxford.

Karlsson-Vinkhuyzen S (2015) The legitimation of global energy governance: A normative exploration In: Mancebo F and Sachs I (eds). Transitions to Sustainability. Springer: The Netherlands, pp. 119-130.

Karlsson-Vinkhuyzen SI (2010) The United Nations and global energy governance: Past challenges, future choices. Global Change, Peace \& Security; 22 (2): 175-195.

Karlsson-Vinkhuyzen SI, Jollands N and Staudt L (2012) Global governance for sustainable energy: The contribution of a global public goods approach. Ecological Economics; 83: 11-18.

Keohane RO (1984) After Hegemony: Cooperation and Discord in the World Political Economy. Princeton University Press: Princeton, NJ.

Keohane RO (1989) International Institutions and State Power: Essays in International Relations Theory. Westview Press: Boulder, Co, USA.

Keohane RO and Victor DG (2011) The regime complex for climate change. Perspectives on Politics; 9 (1): 7-23.

Kérébel C and Keppler JH (2009) La gouvernance mondiale de l'énergie. IFRI: Paris, France.

Kim SE and Urpelainen J (2013) International energy lending: Who funds fossil fuels, who funds energy access for the poor? International Environmental Agreements: Politics, Law and Economics; 13 (4): 411-423.

Kirton JJ (2006) The G8 and Global Energy Governance: Past Performance, St. Petersburg Opportunities. Paper presented at a conference on "The World Dimension of Russia's Energy Security", sponsored by the Moscow State Institute of International Relations (MGIMO), Moscow, 21 April.

Klare MT (2009) The era of xtreme energy: Life after the age of oil. Huffington Post, 22 November.

Klare MT (2012) The Race for What's Left. Metropolitan Books: New York.

Kohl WF (1983) International Institutions for Energy Management. Gower: Aldershot, UK.

Kohl WL (2010) Consumer country energy cooperation: The International Energy Agency and the global energy order In: Goldthau A and Witte JM (eds) Global Energy Governance: The New Rules of the Game. Brookings Institution Press: Washington DC, pp. 195-220.

Konoplyanik A and Walde T (2006) Energy Charter Treaty and its role in international energy. Journal of Energy \& Natural Resources Law; 24 (4): 523.

Krasner SD (1983) International Regimes. Cornell University Press: Ithaca, NY.

Kuzemko C, Belyi A, Goldthau A and Keating MF (2012) Dynamics of Energy Governance in Europe and Russia. Palgrave Macmillan: Basingstoke, UK.

Leal-Arcas R and Filis A (2013) The fragmented governance of the global energy economy: A legal-institutional analysis. The Journal of World Energy Law \& Business; 6 (4): 348-405.

Leal-Arcas R, Filis A and Abu Ghosh ES (2015) International Energy Governance: Selected Legal Issues. Edward Elgar: Cheltenham, UK.

LeBillon P (2005) Fuelling War: Natural Resources and Armed Conflict. Routledge for the International Institute for Strategic Studies: London.

Lesage D and Van de Graaf T (2013) Thriving in complexity? The OECD system's role in energy and taxation. Global Governance; 19 (1): 83-92.

Lesage D, Van de Graaf T and Westphal K (2009) The G8's role in global energy governance since the 2005 gleneagles summit. Global Governance; 15 (2): 259-277.
Lesage D, Van de Graaf T and Westphal K (2010a) Global Energy Governance in a Multipolar World. Ashgate Publishing: Farnham, UK

Lesage D, Van de Graaf T and Westphal K (2010b) G8+5 collaboration on energy efficiency and IPEEC: Shortcut to a sustainable future? Energy Policy; 38 (11): 6419-6427.

Leverett F (2010) Consuming energy: Rising powers, the International Energy Agency, and the global energy architecture In: Alexandroff AS and Cooper AF (eds) Rising States, Rising Institutions: Challenges for Global Governance Brookings Institution Press: Washington DC, pp 240-265.

Lewis JI (2014) The rise of renewable energy protectionism: Emerging trade conflicts and implications for low carbon development. Global Environmental Politics; 14 (4): 10-35.

Lima MGB and Gupta J (2013) The policy context of biofuels: A case of nongovernance at the global level? Global Environmental Politics; 13 (2): 46-64.

Lutzenhiser L and Shove E (1999) Contracting knowledge: The organizational limits to interdisciplinary energy efficiency research and development in the US and the UK. Energy Policy; 27 (4): 217-227.

Maswood SJ (1990) Oil and American hegemony. Australian Journal of International Affairs; 44 (2): 131-141.

McGowan F (2009) International regimes for energy: Finding the right level for policy In: Scarse I and MacKerron G (eds) Energy for the Future: A New Agenda. Palgrave Macmillan: Basingstoke, UK.

Meierding E (forthcoming) Dismantling the oil wars myth. Security Studies.

Meyer T (2012) Global public goods, governance risk, and international energy. Duke Journal of Comparative \& International Law; 22 (3): 319-347.

Nakhooda S (2011) Asia, the multilateral development banks and energy governance. Global Policy; 2 (s1): 120-132.

Newell P (2011) The governance of energy finance: The public, the private and the hybrid. Global Policy; 2 (s1): 94-105.

Raustiala K and Victor DG (2004) The regime complex for plant genetic resources. International Organization; 58 (2): 277-309.

Renner S (2009) The energy community of Southeast Europe: A neo-functionalist project of regional integration. European Integration Online Papers; 13 (1) $1-21$.

Rhodes RAW (1996) The new governance: Governing without government. Political Studies; 44 (4): 652-667.

Risse T (2004) Transnational governance and legitimacy, Unpublished Manuscript, http://userpage.fu-berlin.de/ atasp/texte/tn_governance_benz.pdf, accessed September 2015.

Roehrkasten S (2015) Global Governance on Renewable Energy. Springer: Wiesbaden, Germany.

Rose C (2015) International Anti-Corruption Norms. Oxford University Press: Oxford.

Rosenau JN and Czempiel EO (eds) (1992) Governance without Government: Order and Change in World Politics. Cambridge University Press: Cambridge.

Ross ML (2012) The Oil Curse: How Petroleum Wealth Shapes the Development of Nations. Princeton University Press: Princeton, NJ.

Scholte JA (2005) Globalization: A Critical Introduction. Palgrave Macmillan: Basingstoke, UK.

Smith B (2004) Oil wealth and regime survival in the developing world, 1960-1999. American Journal of Political Science; 48 (2): 232-246.

Sovacool BK and Florini A (2012) Examining the complications of global energy governance. Journal of Energy \& Natural Resources Law.; 30 (3): 235-263.

Strange S (1994) States and Markets. Continuum: London.

Strange S (1996) The Retreat of the State: The Diffusion of Power in the World Economy. Cambridge University Press: New York, USA.

Suding $\mathrm{PH}$ and Lempp $\mathrm{P}(2007)$ The multifaceted institutional landscape and processes of international renewable energy policy. IAEE Newsletter, $2^{\text {nd }}$ quarter: 4-9.

Szulecki K, Pattberg P and Biermann F (2011) Explaining variation in the effectiveness of transnational energy partnerships. Governance; 24 (4): $713-736$.

Tillerson R (2013) Capitalizing on the coming era of energy abundance, Address to Texas Alliance of Energy Producers, Houston, 2 April, retrieved at http:// corporate.exxonmobil.com/en/company/news-and-updates/speeches/capitaliz ing-on-coming-era-of-energy-abundance/.

Urpelainen J and Van de Graaf T (2013) The International Renewable Energy Agency: A success story in institutional innovation? International Environmental Agreements: Politics, Law and Economics; 15 (2): 159-177.

Van Asselt H (2014) Governing the transition away from fossil fuels: The role of international institutions. SEI Working Paper No. 2014-07, Stockholm Environment Institute: Oxford, UK.

Van de Graaf T (2012) Obsolete or resurgent? The International Energy Agency in a changing global landscape. Energy Policy; 48, 233-241.

Van de Graaf T (2013a) Fragmentation in global energy governance: Explaining the creation of IRENA. Global Environmental Politics; 13 (3): 14-33.

Van de Graaf T (2013b) The Politics and Institutions of Global Energy Governance. Palgrave Macmillan: Basingstoke, UK. 
Van de Graaf T (2015) The IEA, the new energy order and the future of global energy governance In: Lesage D and Van de Graaf T (eds) Rising Powers and Multilateral Institutions. Palgrave Macmillan, pp 79-95.

Van de Graaf T and Lesage D (2009) The International Energy Agency after 35 years: Reform needs and institutional adaptability. Review of International Organizations; 4 (3): 293-317.

Van de Graaf T and Westphal K (2011) The G8 and G20 as global steering committees for energy: Opportunities and constraints. Global Policy; 2 (s1): 19-30.

Van de Graaf T and Verbruggen A (2015) The oil endgame: Strategies of oil exporters in a carbon constrained world. Environmental Science \& Policy; 52: 456-462.

Van de Graaf T, Sovacool BK, Ghosh A, Kern F and Klare MT (eds) (2016) States, markets and institutions: Integrating International Political Economy and global energy politics In: Handbook on the International Political Economy of Energy. Palgrave Macmillan: Basingstoke, UK.

Weinar L (2016) Blood Oil: Tyrants, Violence, and the Rules that Run the World. Oxford University Press: Oxford.

Westphal K (2006) Energy policy between multilateral governance and geopolitics: Whither Europe? Internationale Politik und Gesellschaft; 4: $44-62$.
Wilson EJ (1987) World politics and international energy markets. International Organization; 41 (1): 125-149.

Wilson JD (2015) Multilateral organisations and the limits to international energy cooperation. New Political Economy; 20 (1): 85-106.

\section{Additional information}

Competing interests: The author declares no competing financial interests.

Reprints and permission information is available at http://www.palgrave-journals.com/ pal/authors/rights_and_permissions.html

How to cite this article: Van de Graaf T (2016) Global energy governance: a review and research agenda. Palgrave Communications. 2:15047 doi: 10.1057/palcomms.2015.47.

(c) (i) This work is licensed under a Creative Commons Attribution 4.0 International License. The images or other third party material in this article are included in the article's Creative Commons license, unless indicated otherwise in the credit line; if the material is not included under the Creative Commons license, users will need to obtain permission from the license holder to reproduce the material. To view a copy of this license, visit http://creativecommons.org/licenses/by/4.0/ 